\title{
O conhecimento do enfermeiro e sua atuação no atendimento intra- hospitalar à vítima de parada cardiorrespiratória
}

\author{
The nurse's knowledge and its performance in intra-hospital care to cardiorrespiratory stop \\ victim
}
El conocimiento de la enfermera y su desempeño en la atención intrahospitalaria al cardiorrespiratorio detenga víctima

Ana Paula Oliveira Lopes ${ }^{1 \star}$, Guilherme Bicalho Nogueira'.

\begin{abstract}
RESUMO
Objetivo: Identificar se enfermeiros de um hospital no norte do estado do Espírito Santo possuem conhecimento técnico/científico do suporte avançado de vida sobre a Parada Cardiorrespiratória (PCR) no adulto, baseado nas novas diretrizes da American Heart Association (AHA) de 2018. Métodos: Estudo de campo com abordagem quantitativa voltada para enfermeiros, elaborado com base nas diretrizes da AHA 2018, com questões objetivas semiestruturadas referentes ao conhecimento técnico científico do Suporte Avançado de Vida (SAV) sobre a PCR no adulto. Resultados: Participaram da pesquisa 30 enfermeiros, desses, 66.67\% responderam que fizeram curso teórico prático de Advanced Cardiovascular Life Support (ACLS) após a faculdade. Quanto ao reconhecimento dos sinais de PCR, nenhum enfermeiro respondeu de forma correta e $73.33 \%$ não sabem qual atitude imediata a ser tomada após o reconhecimento da PCR, mostrando desconhecimento das diretrizes da AHA. Conclusão: O estudo apontou a necessidade de treinamento regular dos profissionais entrevistados, pois a falta de especialização somada ao desconhecimento das diretrizes da AHA contribuiu para um conhecimento abaixo do desejado, resultando em um baixo percentual de respostas corretas no que tange aos conhecimentos da PCR no ACLS adulto.
\end{abstract}

Palavras-chave: Enfermeiro, Suporte avançado de vida, Ressuscitação cardiopulmonar.

\begin{abstract}
Objective: To identify whether nurses in a hospital in the north of the state of Espírito Santo have technical / scientific knowledge of advanced life support on Cardiorespiratory Arrest (CRP) in adults, based on the new guidelines of the American Heart Association (AHA) of 2018. Methods: Field study with a quantitative approach aimed at nurses, elaborated based on the guidelines of AHA 2018, with semi-structured objective questions referring to the scientific technical knowledge of the Advanced Life Support (VAS) on adult CPA. Results: Thirty nurses participated in the survey, $66.67 \%$ of whom answered that they took a theoretical and practical course on Advanced Cardiovascular Life Support (ACLS) after college. As for the recognition of signs of CRP, no nurse responded correctly and $73.33 \%$ do not know what immediate action to take after the recognition of CRP, showing ignorance of the AHA guidelines. Conclusion: The study pointed out the need for regular training of the interviewed professionals, since the lack of specialization added to the lack of knowledge of the AHA guidelines contributed to a knowledge below the desired level, resulting in a low percentage of correct answers regarding the knowledge of PCR in the Adult ACLS.
\end{abstract}

Keywords: Nurse, Advanced life support, Cardiopulmonary resuscitation.

${ }^{1}$ Faculdade Vale do Cricaré (FVC), São Mateus - ES. *E-mail: paulaollp@hotmail.com 


\section{RESUMEN}

Objetivo: Identificar si los enfermeros de un hospital del norte del estado de Espírito Santo tienen conocimientos técnico-científicos de soporte vital avanzado en Parada Cardiorrespiratoria (PCR) en adultos, con base en las nuevas directrices de la American Heart Association (AHA) de 2018. Métodos: Estudio de campo con abordaje cuantitativo dirigido a enfermeros, elaborado en base a los lineamientos de la AHA 2018, con preguntas objetivas semiestructuradas referentes al conocimiento científico técnico del Soporte Vital Avanzado (VAS) sobre PCR en adultos. Resultados: Treinta enfermeras participaron en la encuesta, $66.67 \%$ de las cuales respondió que realizó un curso teórico y práctico sobre Soporte Vital Cardiovascular Avanzado (SVCA) después de la universidad. En cuanto al reconocimiento de signos de PCR, ninguna enfermera respondió correctamente y el 73,33\% desconoce qué acción inmediata tomar tras el reconocimiento de PCR, mostrando desconocimiento de las pautas de la AHA. Conclusión: El estudio señaló la necesidad de una formación periódica de los profesionales entrevistados, ya que la falta de especialización sumada al desconocimiento de las guías de la AHA contribuyó a un conocimiento por debajo del nivel deseado, resultando en un bajo porcentaje de aciertos en cuanto a la conocimiento de la PCR en el ACLS adulto.

Palabras clave: Enfermera, Soporte vital avanzado, Reanimación cardiopulmonar.

\section{INTRODUÇÃO}

Segundo a American Heart Association (AHA), a parada cardiorrespiratória (PCR) é considerada uma intercorrência de extrema emergência, e consiste em uma interrupção severa e repentina das atividades respiratórias e mecânicas do coração, levando a um ritmo cardíaco inadequado ou ausência dele, e consequentemente ao risco de morte às vítimas acometidas (AHA, 2015). Desse modo, se o socorro não for imediato, podem ocorrer danos cerebrais irreversíveis, principalmente se a PCR durar mais de 5 minutos (MOURA LTR, et al., 2012).

Dados da Organização Mundial da Saúde (OMS) apontam que as Doenças Cardiovasculares (DCV) foram a causa de 17,7 milhões de mortes em 2015 o que representa aproximadamente $31 \%$ de todos os óbitos em nível global. No Brasil, as DCV também ganham destaque com cerca de $28,6 \%$ de todas as causas de óbito no ano de 2011. Na pesquisa mais recente no estado do Espírito Santo, os dados são de $32,5 \%$ de mortalidade de Infarto Agudo do Miocárdio (IAM), com maior prevalência no sexo masculino. Inúmeros são os fatores que podem estar ligados ao aumento dessas doenças, possivelmente pelo envelhecimento populacional, incorporação de novas tecnologias ajudando no diagnóstico precoce das doenças e queda da letalidade (BRASIL, 2017).

Uma pesquisa realizada em 2012 revela que várias doenças e condições clínicas podem levar a uma PCR. Moura LTR, et al. (2012), faz um paralelo associando doenças como: "infarto agudo do miocárdio, obstrução de vias aéreas, hemorragia intensa, quase afogamento, abuso de drogas ilícitas, arritmias cardíacas, episódio de obstrução das artérias coronárias", entre outras as que alteram o ritmo cardíaco (MOURA LTR, et al., 2012).

A detecção rápida e as ações imediatas levam ao sucesso do atendimento e, para que isso ocorra, é necessária avidez em várias etapas que vão desde o reconhecimento dos sinais de parada até a efetiva realização das manobras avançadas, o que exige da equipe concentração e empenho nos críticos 30 minutos pré e pós-reanimação cardiopulmonar (RCP) (AHA, 2015).

Rocha FAS, et al. (2012) aponta que o sucesso do atendimento está diretamente ligado a agilidade e qualidade nos procedimentos realizados pela equipe, seja pelo suporte básico de vida (SBV) ou pelo suporte avançado de vida (SAV), pela união, sincronismo, capacitação da equipe e estrutura organizada. Outro autor afirma que o procedimento adequado em tempo hábil são princípios fundamentais para reversão do quadro, restaurando a circulação e oxigenação da vítima em PCR, devolvendo de $25 \%$ a $33 \%$ de sangue oxigenado, principalmente para o cérebro e coração, órgãos e tecidos, até o retorno espontâneo da função cardíaca e respiratória do indivíduo, no intuito de salvar a vida (ARAÚJO LP, et al., 2012). 
Nessa perspectiva, o enfermeiro deve ter competência, manter-se atualizado e preparado para assistir as possíveis vítimas em PCR com conhecimento científico, prático e técnico, além de promover capacitações teóricas e práticas aos demais membros de sua equipe. Ele necessita iniciar as manobras de reanimação cardiorrespiratórias o mais breve possível, com objetivo de restabelecer a circulação sanguínea, evitando assim lesão cerebral, o que demanda várias ações como decisões breves e concretas, garantindo segurança e liderança a toda equipe envolvida e principalmente reduzir todos os fatores que colocam em risco a vida do paciente (ROCHA FAS, et al., 2012).

Portanto, a equipe de enfermagem desempenha papel importante no manejo da PCR juntamente com a equipe médica, ponderando que a sobrevivência do paciente depende diretamente da eficácia dessa atuação e a execução de ações rápidas e acertadas (SILVA AB e MACHADO RC, 2013).

Desta forma, o presente estudo tem o objetivo de identificar se os enfermeiros de um hospital no norte do estado do Espírito Santo possuem conhecimento técnico/científico do SAV sobre a PCR no adulto, baseado nas diretrizes da AHA de 2018.

\section{MÉTODOS}

Este é um estudo de campo de caráter exploratório e descritivo com abordagem quantitativa realizado com enfermeiros de um hospital público, no norte do estado do Espírito Santo. A equipe de enfermagem conta com 44 enfermeiros, 232 técnicos de enfermagem e 24 auxiliares de enfermagem e possui em torno de 320 leitos mantidos pela Secretaria de Estado da Saúde.

A amostra foi composta por enfermeiros de plantão nos dias da aplicação dos questionários que demonstraram interesse em participar da pesquisa assinando o Termo de Consentimento Livre e Esclarecido (TCLE). Foram excluídos da amostra 4 enfermeiros com menos de um ano de atuação no hospital, 2 que foram cedidos a outra unidade hospitalar, 5 que estavam de folga/permuta, 2 de férias e 1 que se recusou a participar do estudo, totalizando 30 enfermeiros participantes da pesquisa.

$\mathrm{O}$ instrumento utilizado contou com questões objetivas, semiestruturadas, baseado nas diretrizes da AHA de 2018 com perguntas divididas: a primeira com objetivo traçar o perfil da formação acadêmica; a segunda a fim de verificar a experiência profissional; e a terceira para levantar o conhecimento apresentado pelos enfermeiros e qual conduta adotada em relação a PCR. O mesmo foi adaptado do instrumento de coleta de dados elaborado por Bellan MC, et al. (2010), com perguntas organizadas em sequência lógica e compatível com as novas recomendações da AHA para a PCR no Suporte Avançado de Vida em Cardiologia (ACLS) 2018.

Os dados foram transferidos para planilhas eletrônicas e tabulados com auxílio do Programa Microsoft Excel 2016. A análise foi por meio de estatística descritiva simples, exibida em frequência absoluta e porcentagens, organizadas em forma de tabela e gráficos através do programa Statistical Package for the Social Sciences (SPSS) versão 20,0 para Windows, e discutidas de acordo com o tema em questão.

O projeto da pesquisa foi encaminhado para avaliação e apreciação do Comitê de Ética em Pesquisa em Seres Humanos (CEP) da Faculdade Vale do Cricaré (FVC). Após autorização do projeto pelo comitê, em 05 de junho de 2019, com autorização da pesquisa, Parecer n. 3.370.275, foi enviado uma carta convite para coleta de dados para a coordenação de enfermagem do hospital solicitando colaboração para realizar as entrevistas com os enfermeiros em horários e dias pré-estabelecidos pela mesma.

A participação dos profissionais foi voluntária, não envolvendo riscos uma vez que nenhum procedimento invasivo ou potencialmente lesivo foi aplicado. Os enfermeiros foram informados da possibilidade de se recusar a qualquer momento de participar ou deixar de responder perguntas que por qualquer motivo não lhe seja conveniente, não acarretando nenhum prejuízo pessoal, tal liberdade garantida com base na Resolução CNS no $466 / 12$ e 510/16.

\section{RESULTADOS}

Questionados se realizaram algum curso teórico ou prático com o conteúdo de ACLS após a conclusão da graduação de enfermagem, $66.67 \%$ responderam que sim. Os $33.33 \%$ que responderam não foram arguidos 
sobre os possíveis motivos que impossibilitava de manter a atualização (Gráfico 1). Ao avaliar as respostas quanto ao curso de atualização em ACLS da AHA nos últimos dois anos, a maioria $83.33 \%$ responderam que não e somente $16.67 \%$ fizeram o curso. Desses, as fontes utilizadas para fazer a atualização foram equilibradas entre cursos $40.00 \%$ e leitura de livros $40.00 \%$.

Contrapondo a resposta anterior, quando questionados sobre o conhecimento das novas recomendações de 2018 da AHA, $30.00 \%$ enfermeiros responderam que conheciam, contra $70.00 \%$ que desconhecem as novas diretrizes.

Tabela 1 - Distribuição das variáveis de formação profissional dos enfermeiros. 2019.

\begin{tabular}{lcc}
\hline Variável & N & $\%$ \\
\hline Curso com conteúdo de ACLS $^{\mathbf{a}}$ & & \\
\hline Sim & 20 & 66,67 \\
Não & 10 & 33,33 \\
\hline Atualização em ACLS da AHA & \\
\hline Sim & & \\
Através de: Cursos & 5 & 16,67 \\
Palestras & 2 & 40,00 \\
Leitura de Livros & 1 & 20,00 \\
Não & 2 & 40,00 \\
\hline Conhece as novas diretrizes da AHA $^{\mathbf{b}} \mathbf{2 0 1 8}^{2018}$ & 25 & 83,33 \\
\hline Sim & & \\
Não & 9 & 30,00 \\
\hline Total & 21 & 70,00 \\
\hline
\end{tabular}

Legenda: ${ }^{\text {a }} \mathrm{ACLS}=$ Advanced Cardiovascular Life Support; ${ }^{\mathrm{b}} \mathrm{AHA}=$ American Heart Association.

Fonte: Lopes APO, et al., 2021.

Gráfico 1 - Fatores que impossibilitam os enfermeiros a manter atualização do curso de ACLS. 2019.

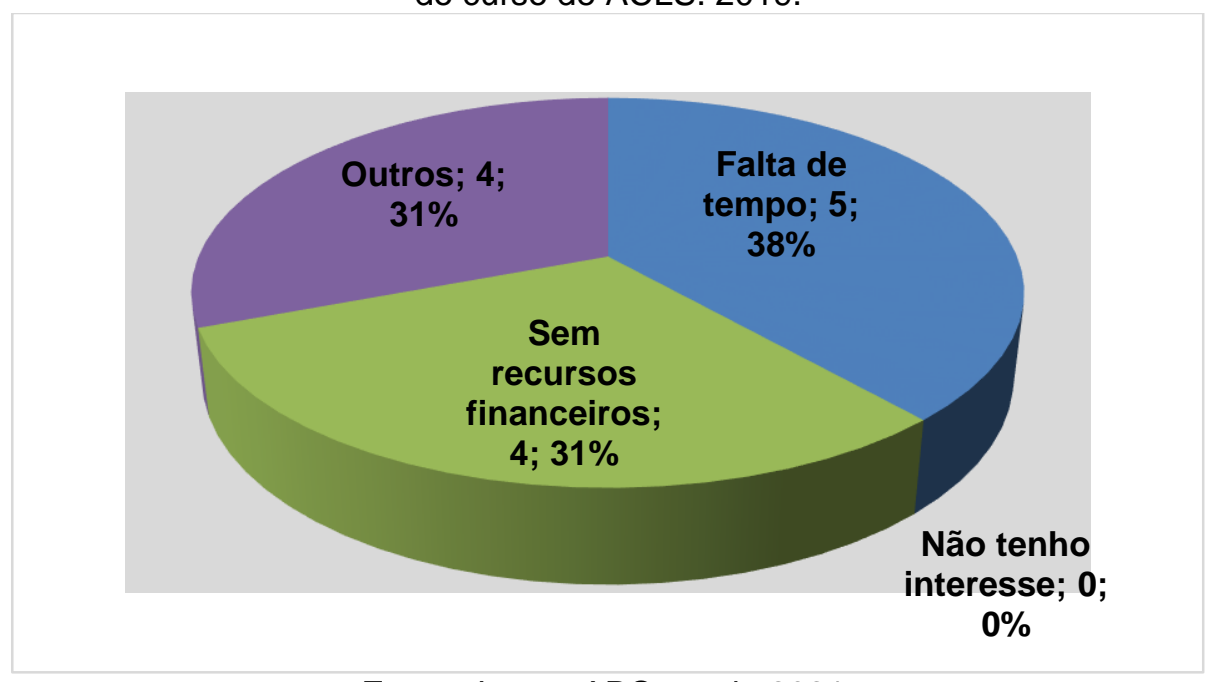

Fonte: Lopes APO, et al., 2021.

Quando perguntados se o hospital oferecia educação continuada/permanente sobre o tema de PCR e ACLS, $93.33 \%$ afirmaram que nunca foi ofertado tal tema, contrapondo a resposta de $6.67 \%$ que confirmaram que existe a oferta (Tabela 2). E desses, $6.67 \%$ enfermeiros quando arguidos se participam dos treinamentos oferecidos, $100 \%$ deles responderam que sim.

Todos profissionais, $100 \%$, foram unanimes em responder que já participaram de um atendimento a uma vítima de PCR em seu setor de trabalho no hospital, o que comprova a necessidade de ter profissionais de todos os setores na pesquisa. Foi questionado aos enfermeiros os fatores que os interferem de prestar um atendimento de alta qualidade a uma vítima de PCR (Gráfico 2). A questão foi de múltipla escolha, portanto um entrevistado pode assinalar mais de uma opção. 
Tabela 2 - Dados relacionados a variáveis sócio profissional dos enfermeiros, 2019.

\begin{tabular}{lcc}
\hline Variável & $\mathbf{N}$ & $\%$ \\
\hline Educação permanente & 2 & \\
\hline Sim & 28 & 9,67 \\
Não & & \\
\hline Já participou do atendimento a vítima em PCR & \\
\hline Sim & 30 & 100,00 \\
Não & 0 & 0 \\
\hline Total & $\mathbf{3 0}$ & - \\
\hline
\end{tabular}

Legenda: ${ }^{\text {a }} \mathrm{PCR}=$ Parada Cardiopulmonar.

Fonte: LOPES APO, et al., 2021.

Quando perguntados sobre fatores que implicam no atendimento de qualidade, a opção mais assinalada foi a falta de habilidades técnicas com $27 \%$, seguidos das opções de inexperiência com $24 \%$, falta de conhecimento com $21 \%$, insegurança $19 \%$, e outros fatores foram assinalados com $8 \%$. Um entrevistado, $1 \%$, não assinalou nenhum fator deixando a questão em branco.

Gráfico 2 - Fatores que interferem o profissional enfermeiro de realizar um atendimento de qualidade a uma vítima de PCR. 2019.

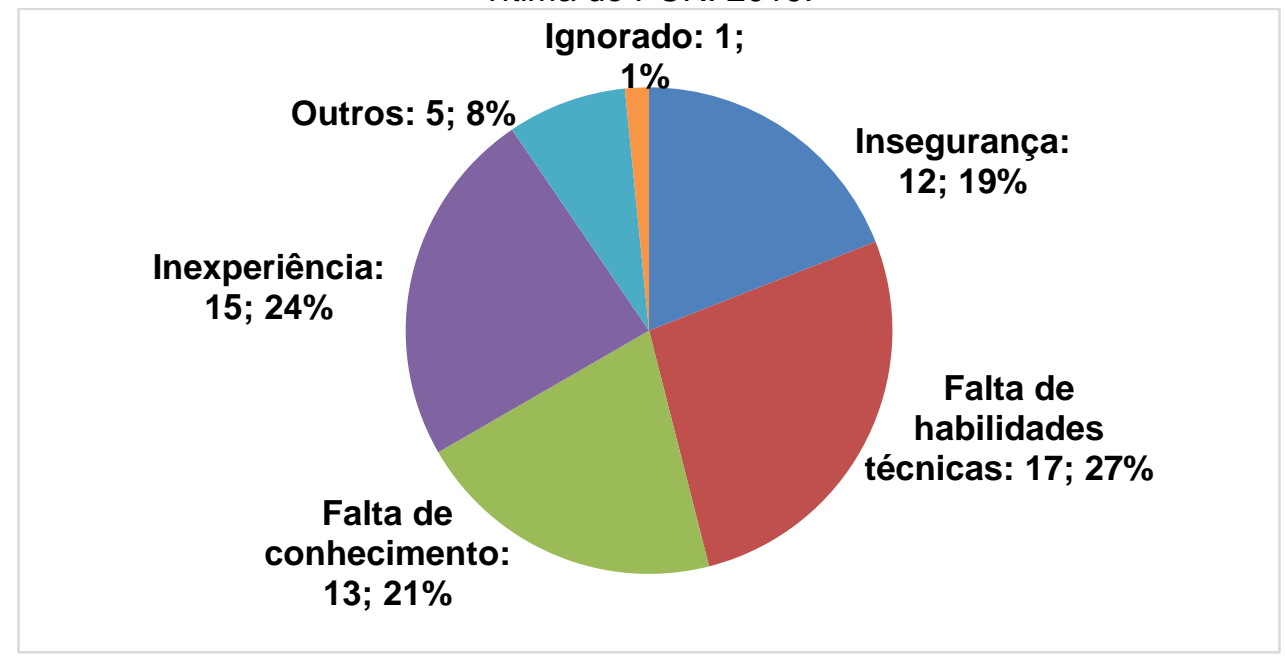

Fonte: Lopes APO, et al., 2021.

$\mathrm{Na}$ análise de dados a respeito do conhecimento dos enfermeiros no momento da PCR no ACLS adulto (Tabela 3), as respostas referentes a detecção dos sinais de PCR, mostrou que nenhum profissional sabe reconhecer corretamente. Houve então um equilíbrio entre as respostas parcialmente correta, com $50.00 \% \mathrm{e}$ incorreta com $50.00 \%$. Dos 15 enfermeiros que responderam parcialmente correta, 11 marcou cianose como um sinal de PCR.

A conduta imediata a ser tomada pelo profissional logo após a identificação da PCR, mostrou que $26.67 \%$ sabem como agir e $73.33 \%$ não sabem o que fazer. Quanto aos ritmos passíveis de choque, somente $10.00 \%$ responderam corretamente à questão, $30.00 \%$ responderam parcialmente correta, $56.67 \%$ incorretamente, e $3.33 \%$ não responderam à questão. Já a atitude imediata a ser tomada logo após o procedimento de desfibrilação em ritmos passíveis de choque, $83.33 \%$ dos enfermeiros responderam à questão incorretamente, contra $16.67 \%$ que acertaram a questão.

Observou que $86.67 \%$ dos enfermeiros não sabiam responder a profundidade necessária que deve ser aplicada nas compressões torácicas externas no atendimento à vítima em PCR. Somente $13.33 \%$ acertaram a questão. $\mathrm{Na}$ velocidade por minutos que deve ser empregada nas compressões torácicas, respondeu corretamente $26.67 \%$, sendo que $70.00 \%$ responderam incorretamente e $3.33 \%$ não responderam à questão.

Em relação à quantidade de carga elétrica utilizada para desfibrilar o paciente em ritmos chocáveis, verificou-se que alguns profissionais não responderam à questão. Nos aparelhos monofásicos, somente 
$10.00 \%$ dos profissionais responderam corretamente a quantidade de carga, $80.00 \%$ responderam incorretamente e $10.00 \%$ deixaram a questão em branco. Para os aparelhos bifásicos, 33.33\% responderam corretamente, 53.33\% responderam incorretamente e 13.33\% deixaram a questão sem resposta. Quanto à frequência das ventilações por minuto nos pacientes com VAA, somente $23.33 \%$ responderam corretamente à questão contra $76.67 \%$ que não sabem a frequência.

A questão sobre a relação compressão/ventilação sem VAA e com VAA chama atenção, pois as respostas incorretas em ambas as questões mantiveram quase o mesmo percentual. Responderam corretamente $53.33 \%$ a relação compressão/ventilação sem VAA e incorretamente $46.67 \%$ dos entrevistados. Já a relação compressão/ventilação com VAA, $50.00 \%$ respondeu corretamente, $46.67 \%$ incorretamente e $3.33 \%$ não responderam à questão. Os fármacos utilizados chamam atenção pois nenhum enfermeiro sabe ao certo quais são utilizados, $43.33 \%$ responderam parcialmente correto e $56.67 \%$ responderam incorretamente.

Tabela 3 - Conhecimento dos enfermeiros no atendimento a PCR ${ }^{a}$ no ACLS ${ }^{b}$ adulto. 2019

\begin{tabular}{|c|c|c|c|c|}
\hline Variável & 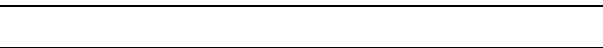 & & $\mathbf{N}$ & $\%$ \\
\hline & & Correta & 0 & $0 \%$ \\
\hline Datonمãn da & & Parcialmente correta & 15 & $50.00 \%$ \\
\hline Detecçao da & $\mathbf{S R}^{\mathbf{a}}$ & Incorreta & 15 & $50.00 \%$ \\
\hline & & Não realizada & - & - \\
\hline & & Correta & 8 & $26.67 \%$ \\
\hline Conduta ime & ata após identificação da PCR ${ }^{a}$ & Incorreta & 22 & $73.33 \%$ \\
\hline & & Não realizada & - & - \\
\hline & & Correta & 3 & $10.00 \%$ \\
\hline Ditma nas & Siodo ohoru & Parcialmente correta & 9 & $30.00 \%$ \\
\hline Ritmos pass! & Is de choque & Incorreta & 17 & $56.67 \%$ \\
\hline & & Não realizada & 1 & $3.33 \%$ \\
\hline & & Correta & 5 & $16.67 \%$ \\
\hline Qual atıtude I & ediata deve ser tomada logo apos a & Incorreta & 25 & $83.33 \%$ \\
\hline & & Não realizada & - & - \\
\hline & & Correta & 4 & $13.33 \%$ \\
\hline Profundidade & las compressões & Incorreta & 26 & $86.67 \%$ \\
\hline & & Não realizada & - & - \\
\hline & & Correta & 8 & $26.67 \%$ \\
\hline Velocidade $\mathbf{d}$ & compressões & Incorreta & 21 & $70.00 \%$ \\
\hline & & Não realizada & 1 & $3.33 \%$ \\
\hline & & Correta & 3 & $10.00 \%$ \\
\hline & Desfibrilador monofásico & Incorreta & 24 & $80.00 \%$ \\
\hline Carga & & Não realizada & 3 & $10.00 \%$ \\
\hline elétrica & & Correta & 10 & $33.33 \%$ \\
\hline & Desfibrilador Bifásico & Incorreta & 16 & $53.33 \%$ \\
\hline & & Não realizada & 4 & $13.33 \%$ \\
\hline & & Correta & 7 & $23.33 \%$ \\
\hline Frequência d & ventilações com VAAc & Incorreta & 23 & $76.67 \%$ \\
\hline & & Não realizada & - & - \\
\hline & & Correta & 16 & $53.33 \%$ \\
\hline & Sem VAA & Incorreta & 14 & $46.67 \%$ \\
\hline Relaçao & & Não realizada & - & - \\
\hline ventilaçao X & & Correta & 15 & $50.00 \%$ \\
\hline Compressao & Com VAA & Incorreta & 14 & $46.67 \%$ \\
\hline & & Não realizada & 1 & $3.33 \%$ \\
\hline & & Correta & 0 & $0 \%$ \\
\hline Fórmannc uti & pdoc ne PCRa & Parcialmente correta & 13 & $43.33 \%$ \\
\hline rarmacos uti & ados na PCR & Incorreta & 17 & $56.67 \%$ \\
\hline & & Não realizada & - & - \\
\hline
\end{tabular}

Legenda: a PCR = Parada Cardiorrespiratória; b $\mathrm{ACLS}=$ Advanced Cardiovascular Life Support;

c $\mathrm{VAA}=$ Via Aérea Avançada.

Fonte: Lopes APO, et al., 2021. 


\section{DISCUSSÃO}

Em uma pesquisa realizada com 129 enfermeiros, a fim de avaliar o conhecimento dos mesmos no atendimento a uma PCR, mostrou que os entrevistados que realizaram curso de SAVC, cursos oferecidos pela prefeitura local, cursos através de internet, palestras ou periódicos, há menos de 2 anos, apresentaram maior conhecimento do que os que não realizaram nenhum curso (MORAES TPR e PAIVA EF, 2017). A busca por atualização é estimulada pela percepção de barreiras nas práticas assistenciais do enfermeiro (SALAZAR ERS, et al., 2017).

O resultado do Gráfico 1, vem de encontro à pesquisa realizada pela FIOCRUZ, onde 24,0\% referem "falta de condições financeiras", seguidos de falta de tempo/motivação/estímulo com $21.7 \%$ das respostas, falta de apoio institucional com 10.6\%, entre outros motivos (COREN, 2015). Segundo Bellan MC, et al. (2010), no país são oferecidos cursos regulares de SBV e SAV, sob a supervisão e permissão da AHA, porém não é acessível financeiramente, interferindo na busca à capacitação pelo profissional o que admite os dados obtidos na pesquisa.

Os resultados sobre atualização em ACLS obtiveram dados semelhantes a uma pesquisa realizada em Londrina-PR onde $85.2 \%$ dos entrevistados afirmaram nunca ter participado de cursos de atualização em ACLS (PRESTES JN e MENETRIER JV, 2017). Comparando os dois resultados com a pesquisa realizada por Morais TPR e Paiva EF (2017), os dados divergem, pois 76.7\% dos enfermeiros fizeram o curso de SBV ou SAV ao longo da carreira, desses, $53.5 \%$ fizeram o curso em menos de 2 anos. Vale ressaltar que a prefeitura de Campinas em parceria com o Serviço de Atendimento Móvel de Urgência (SAMU), oferta cursos periodicamente aos profissionais.

A pesquisa de Salazar ERS, et al. (2017), assegurou que o desconhecimento do protocolo atual causa prejuízos na assistência, gerando assim impactos nas taxas de sobrevida dos pacientes vítimas de PCR. As chances de sobrevida de uma vítima em PCR estão diretamente relacionadas ao atendimento seguro e eficaz dos profissionais, sendo uma das emergências mais temidas pelos profissionais. Para realizar tal atendimento o profissional deve ter preparo técnico científico prévio, fazendo-se necessário a atualização profissional (SILVA LGS, et al., 2018). Dessa forma, alcançará (aumenta-se consideravelmente a possibilidade de) sucesso nas manobras, pois os protocolos de RCP sofrem revisões periódicas a fim de se tornar cada vez mais eficazes (MOURA LTR, et al., 2012).

Resultados obtidos sobre a oferta de educação continuada/permanente vão de encontro com uma pesquisa realizada por Barbosa JSL, et al. (2018) com 22 enfermeiros, onde levantou $83.33 \%$ de respostas positivas quanto a oferta de educação permanente no setor de trabalho contra $5.55 \%$ de profissionais que não souberam responder à questão e $11.11 \%$ de profissionais que deixaram a questão em branco. Um estudo mostrou melhora significativa do conhecimento dos enfermeiros após o treinamento de PCR, mas também mostrou queda, pouco significativo, no conhecimento após 3 meses (BELLAN MC, 2010). Oliveira SFG, et al. (2018), afirma que a falta de treinamento e/ou tempo muito extenso para atualização pode refletir negativamente no conhecimento dos profissionais enfermeiros e aborda que os treinamentos devem ser realizados a cada três meses de acordo com a realidade de cada instituição.

Um estudo observacional realizado no Japão constatou que pessoas treinadas são mais propensas realizar a PCR em comparação aquelas que não foram habilitadas para tal, dissimilando temor, medo do fracasso e até mesmo vergonha como possíveis pretextos para a não realização do procedimento (TANIGAWA K, et al., 2011).

Silva LGS, et al. (2018), em suas pesquisas, afirmam que os profissionais enfermeiros devem se manter atualizados, preparados tecnicamente e cientificamente para agir em situações de PCR, uma vez que o enfermeiro é o profissional, muitas vezes, responsável por reconhecer e iniciar primeiramente o SBV até a chegada da equipe e auxiliar no SAV. Os mesmos autores, com base em outras pesquisas, reforçam que montar estratégias de educação continuada e capacitação com intervalos curtos são medidas que preparam melhor o profissional, culminando a ssim em melhoria da assistência em situações de PCR com redução da mortalidade hospitalar. Reforça também que o profissional deve buscar outras formas de atualização para melhoria de seus rendimentos ao longo do tempo. 
Moura JG, et al. (2019), realizou uma pesquisa com profissionais enfermeiros de uma UTI onde a maioria dos enfermeiros $73.91 \%$, responderam parcialmente correta quanto a identificação dos sinais clínicos da PCR (não reconhecendo inconsciência como sinal), tendo somente $26.09 \%$ de respostas corretas. Outro estudo realizado em São Paulo observou que 100\% dos enfermeiros responderam de forma correta os sinais de PCR (LIMA AR e INVENÇÃO ASS 2017).

O resultado apresentando na conduta imediata a ser tomada frente a identificação da PCR é preocupante, pois a taxa de sobrevida é de $75 \%$ nos primeiros quatro minutos, $15 \%$ entre quatro a doze minutos e somente $5 \%$ após 15 minutos, mostrando a necessidade de intervenção imediata após detecção dos sinais de PCR (ALVES CA, et al., 2013). Moura JG, et al. (2019), também observou $78.26 \%$ de respostas parcialmente correta na questão sobre qual conduta imediata deve ser tomada logo após identificação da PCR contra $21.74 \%$.

Os resultados da pesquisa mostram uma discrepância elevada de um estudo realizado recentemente no norte do Brasil, com 33 enfermeiros, que mostrou $72.0 \%$ acertaram os ritmos passíveis de desfibrilação e somente $28.0 \%$ não acertaram a questão (BARROS FRB e NETO ML, 2018). Podemos citar então a conclusão de Silva AB e Machado RC (2013), na limitação de conhecimento, tanto teórico quanto prático, por parte dos profissionais enfermeiros quanto a avaliação de ritmos cardíacos e manobras para reestabelecer a vítima em PCR, sem esquecer de citar as técnicas e locais das compressões e o intervalo de tempo na administração dos medicamentos utilizados na PCR.

Os resultados podem estar ligados ao estudo de Costa KP, et al. (2015) que identificou que os profissionais enfermeiros transferem a responsabilidade do conhecimento de ritmos cardíacos e manuseio do desfibrilador para a equipe médica.

Alves CA, et al. (2013) afirmaram que $87,5 \%$ dos enfermeiros desconhecem os procedimentos realizados logo após aplicação do choque e afirmam ainda que os profissionais enfermeiros pensam que a administração do choque é a última opção utilizada para salvar a vida do paciente, não realizando portando outro procedimento após a desfibrilação. Outro estudo realizado em Minas Gerais no ano de 2017 apresentou resultados semelhantes uma vez que $73.7 \%$ dos entrevistados também erraram a questão (DIAZ FBBS, et al., 2017).

Todos resultados divergem com os resultados de Moura JG, et al. (2019), que apontou em um estudo recente que $73.26 \%$ dos entrevistados responderam corretamente que deveriam reiniciar as compressões imediatamente logo após o procedimento de desfibrilação e $10.0 \%$ não souberam responder à questão. Vale ressaltar que esse último estudo trouxe um percentual de $92.5 \%$ de profissionais que tinham participado ativamente de cursos de SBV pela AHA em menos de 1 ano (SALAZAR ERS, et al., 2017).

Um estudo realizado com estudantes de enfermagem sobre a profundidade necessária nas compressões torácicas, a maioria $71,7 \%$ acertaram a questão, enquanto menos de metade $21,7 \%$ afirmou que as compressões devem atingir no máximo até $5 \mathrm{~cm}$ de profundidade (OLIVEIRA SS, et al., 2014).

A diferença dos dados apresentados cogita o fato do estudo realizado por Oliveira SS, et al. (2014) ter sido com alunos graduandos de enfermagem que estão mais próximos ao tema em questão do que os profissionais pesquisados aqui. Advertindo ainda que tal procedimento é conduta importante no processo de RCP de alta qualidade uma vez que, se bem realizada, garante manutenção da circulação e da oxigenação, já que é ela quem conduz oxigênio para órgãos vitais.

Alguns estudos mostram um elevado percentual de acerto na questão da velocidade das compressões como um realizado com enfermeiros de um hospital em Minas Gerais, onde houve $50 \%$ de acerto na questão (DIAZ FBBS, et al., 2017), outro estudo, Barros FRB e Neto ML (2018), onde $92 \%$ afirmaram que a velocidade deve ser de 100 a 120 compressões por minuto, lembrando que a população estudada foram alunos do curso de pós-graduação em cardiologia e hemodinâmica.

Em relação a carga elétrica utilizada, Lima LCA, et al. (2018) identificaram $53.84 \%$ de respostas corretas nas cargas nos aparelhos monofásicos e bifásico, já Lucas MG, et al. (2018) obteve o resultado de $100 \%$ de acertos nas questões de cargas elétricas em jaules nos aparelhos monofásicos e bifásico. 
Uma pesquisa realizada em um serviço de referência em UE em Rondônia mostrou dados quanto a frequência das ventilações com VAA que vão de encontro aos dados aqui representados, onde 46,15\% acertaram a frequência das ventilações na vítima com VAA contra $53,85 \%$ que respondeu incorretamente (LIMA LCA, et al., 2018).

Estudo realizado com 68 enfermeiros em Goiânia no ano de 2018, mostrou 52.94\% de respostas corretas na relação compressão/ventilação sem VAA e $33.82 \%$ respostas corretas na relação compressão/ventilação com VAA (OLIVEIRA SFG, et al., 2018).

Um estudo realizado em Goiás no ano de 2018, em questão de múltipla escolha sobre fármacos utilizados na PCR, revelou um percentual alto de erros como na pesquisa aqui exposta. As drogas como atropina $(44.4 \%)$, lidocaína (38.9\%), bicarbonato de sódio/noradrenalina/dobutamina $(27.77 \%)$ e até digitálicos e nitroprussiato de sódio (27.8\%), gluconato de cálcio (33.4\%), midazolan $(11.11 \%)$ e por fim fenitanila/fenitoina/adenosina/vasopressina $(5.55 \%)$ foram apontadas pelos enfermeiros como drogas utilizadas na PCR (BARBOSA JSL, et al., 2018).

Uma das mudanças e recomendações realizadas no protocolo de 2010 para 2015 foi que o uso combinado de vasopressina e epinefrina não oferece nenhuma vantagem em comparação ao uso da dose padrão de epinefrina em PCR. Então, para simplificar o algoritmo a vasopressina foi retirada do protocolo. Outra mudança foi a retirada de lidocaína do protocolo em 2010 (AHA, 2015).

\section{CONCLUSÃO}

A PCR é uma emergência que demanda tomada de decisão imediata de procedimentos qualificados e o enfermeiro tem papel fundamental por ser o profissional que, por vezes, permanece ao lado do paciente no ambiente hospitalar, reconhecendo e iniciando as manobras de RCP. O estudo apontou a necessidade de treinamento regular, pois a falta de especialização na área somada ao desconhecimento das diretrizes atualizadas da AHA contribuiu para um conhecimento abaixo do desejado, e resultou em um baixo percentual de respostas corretas na parte de conhecimentos da PCR no ACLS adulto. Sendo assim os resultados reforçam a necessidade de educação permanente/continuada aos enfermeiros sobre o tema, pois seu mau desempenho interfere de maneira negativa no prognóstico do paciente.

\section{REFERÊNCIAS}

1. ALVES CA, et al. Parada cardiorrespiratória e enfermagem: o conhecimento acerca do suporte básico de vida. Cogitare Enferm. 2013; 18: 296-301.

2. AMERICAN HEART ASSOCIATION, 2015. In: Atualização das Diretrizes de RCP e ACE. Disponível em: https://eccguidelines.heart.org/wp-content/uploads/2015/10/2015-AHA-Guidelines Highlights-Portuguese.pdf. Acesso em: 15 out. 2018.

3. AMERICAN HEART ASSOCIATION. 2018. In: Destaques das atualizações focadas em recomendações de 2018 da american heart association para RCP e ACE: suporte avançado de vida cardiovascular e suporte avançado de vida em pediatria. Disponível em: https://eccguidelines.heart.org/wp-content/uploads/2018/10/2018-FocusedUpdates_Highlights_PTBR.pdf. Acesso em: 14 agos. 2019.

4. ARAÚJO LP, et al. Conhecimento da equipe de enfermagem sobre o protocolo Ressuscitação cardiopulmonar no setor de emergência de um Hospital público. Revista Univap, 2012; 18: 66-78.

5. BARBOSA JSL, et al. O conhecimento do profissional de enfermagem frente à parada cardiorrespiratória segundo as novas diretrizes e suas atualizações. Rev Cient. Sena Aires, 2018; 7:117-26.

6. BARROS FRB, NETO ML. Parada e reanimação cardiorrespiratória: conhecimento do enfermeiro baseado nas diretrizes da american heart association 2015. Enferm. Foco, 2018; 9:13-18.

7. BELLAN MC, et al. Capacitação teórica do enfermeiro para o atendimento da parada cardiorrespiratória respiratória. Revista Brasileira de Enfermagem, 2010; 63: 1019 - 1027.

8. BRASIL. Secretaria de Estado da Saúde. Vigilância das Doenças e Agravos não Transmissíveis - DANT's. Boletim epidemiológico, Espírito Santo, n. 1, 2017.

9. COSTA KP, et al. Atuação da equipe de enfermagem no atendimento à parada cardiorrespiratória cerebral. Cultura de los Cuidados, 2015; 19: 147-53.

10. DIAZ FBBS, et al. Conhecimento dos enfermeiros sobre o novo protocolo de ressuscitação cardiopulmonar. Revista de Enfermagem do Centro Oeste Mineiro, 2017; 7: 1-8.

11. LIMA AR, INVENÇÃO ASS. Atuação do enfermeiro na parada cardiorrespiratória de uma unidade de pronto atendimento (UPA). Revista UNILUS Ensino e Pesquisa, 2017; 14: 272-279. 
12. LIMA LCA, et al. Conhecimento do profissional enfermeiro sobre ressuscitação cardiopulmonar em um hospital de urgência em um município no interior da amazônia legal. J Health Sci Inst., 2018;36:120-3.

13. LUCAS MG, et al. Validação de conteúdo de um instrumento para avaliação da capacitação em ressuscitação cardiopulmonar. Reme - Rev Min Enferm, 2018; 22:e-1121.

14. MORAES TPR, PAIVA EF. Enfermeiros da atenção primária em suporte básico de vida. Rev. Ciênc. Med., 2017; 26: 9-18.

15. MOURA JG, et al. Conhecimento e atuação da equipe de enfermagem de um setor de urgência no evento parada cardiorrespiratória. Rev Fund Care Online, 2019; 11:634-640.

16. MOURA LTR, et al. Assistência ao paciente em Parada cardiorrespiratória em Unidade de Terapia Intensiva. Revista da Rede de Enfermagem do Nordeste, 2012; 13: 419-27.

17. OLIVEIRA SFG, et al. Conhecimento de parada cardiorrespiratória dos profissionais de saúde em um hospital público: estudo transversal. Rev Pesq Fisio, 2018; 8:101-109.

18. OLIVEIRA SS, et al. Suporte básico de vida: avaliação do conhecimento dos graduandos de enfermagem. J Health Sci Inst., 2014; 32:53-8.

19. PRESTES JN, MENETRIER JV. Conhecimento da equipe de enfermagem de uma unidade de terapia intensiva adulta sobre parada cardiorrespiratória. Biosaúde, 2017; 19.

20. ROCHA FAS, et al. Atuação da equipe de enfermagem frente à Parada Cardiorrespiratória Intra hospitalar. Revista Enfermagem Centro Oeste Mineiro, 2012; 2: 141-150.

21. SALAZAR ERS, et al. Diretrizes da american heart association para ressuscitação cardiopulmonar: conhecimento de socorristas. Rev. baiana enferm., 2017; 31: e20449.

22. SILVA AB, MACHADO RC. Elaboração de guia teórico de atendimento em parada cardiorrespiratória para enfermeiros. Revista da Rede de Enfermagem do Nordeste, 2013; 14:1014-21.

23. SILVA LGS, et al. Atuação do enfermeiro frente à parada cardiorrespiratória no ambiente intra-hospitalar. Journal of Health Connections, 2018, 3: 27-45.

24. TANIGAWA K, et al. Are trained individuals more likely to perform bystander CPR? An observational study. Resuscitation, 2011; 82:523-8. 